\title{
LEVELS OF SOME HEAVY METALS IN VEGETABLES FROM ARTISANAL MINING SITES OF DILIMI RIVER, BUKURU AND BARKIN LADI NORTH CENTRAL NIGERIA: ANY PUBLIC HEALTH CONCERN?
}

\author{
Orish Ebere Orisakwe ${ }^{1}$ Emmanuel Ayuba Dagur ${ }^{2}$,Herbert Orji Chidi Mbagwu², \\ Nnaemeka Arinze Udowelle ${ }^{1}$, Samuel James Offor ${ }^{2}$ \\ ${ }^{1}$ Department of Experimental Pharmacology \& Toxicology, Faculty of Pharmacy, \\ University of Port-Harcourt, Rivers State, Nigeria \\ ${ }^{2}$ Department of Pharmacology, Faculty of Pharmacy, University of Uyo, Akwa Ibom State, Nigeria
}

\begin{abstract}
Background. North Central Nigeria is the food basket of Nigeria but is also known for its artisanal mining with attendant public health consequences which is hitherto unquantified. Vegetables grown close to these mining sites may be contaminated with heavy metals.

Objective. This study has estimated health risk associated with heavy metals $\mathrm{HM}(\mathrm{Cd}, \mathrm{Cr}, \mathrm{Cu}, \mathrm{Zn}, \mathrm{Se}$ and Ni) in vegetables harvested inform the mining areas of Dilimi, Bukuru and Barkin Ladi by calculating the Daily intake, Target Hazard Quotient (THQ), Hazard Index (HI) and the Cancer risk (CR) for adults and children in the local population.

Material and methods. Vegetable, soil, irrigation water and sediments samples were collected, digested, ashed and analyzed for HM using an Atomic Absorption Spectrometer (AAS).

Results. The concentration of heavy metals in vegetables were in the order $\mathrm{Cd}<\mathrm{Se}<\mathrm{Cr}<\mathrm{Cu}<\mathrm{Ni}<\mathrm{Zn}$. There were higher HM levels in soil than vegetables samples. The daily intake of HM from vegetable consumption decreased in the following order $\mathrm{Cd}<\mathrm{Se}<\mathrm{Cr}<\mathrm{Cu}<\mathrm{Ni}<\mathrm{Zn}$. At least $62.5 \%$ of vegetable samples had THQ values $>1$ in Dilimi, Bukuru and Barkin ladi (Adults) while 13\% of vegetable samples had THQ values $>1$ in children. The THQ of nickel ranged from $0.38-2.73$ and 0.21-1.53 in adults and children respectively. The bio-concentration factor ranged from 0.026-7.52, 0.01-0.36 and 0.0011-1.23 in Dilimi, Bukuru and Barkin Ladi respectively for all the studied heavy metals. The cancer risk values ranged from 0.011-0.04 and 0.00066-0.02 across all the studied areas for adults and children respectively. HI values for adults were all $>1$ and also the total cancer risk was above the acceptable range of 10-4.

Conclusion. Since THQ is $>1$ in most of the samples, HI values $>1$ for adults in all the vegetable and cancer risk above the acceptable limit consumption of vegetables from the study areas is not free of risk.
\end{abstract}

Key words: heavy metal, vegetables, environmental pollution, public health

\section{INTRODUCTION}

Rapid increase in human population has led to the increased demand for food production especially fruits and vegetables which are consumed on a daily basis. In most developing countries, rapid industrialization and urbanization in the 20th century have dramatically increased the discharge of large amounts of wastewater accompanied with toxic chemicals [25]. This waste drain into farmlands or contaminates streams, rivers and local channels that constitute the primary sources of water for irrigation used in growing vegetables $[4,8$, 22]. Several researchers have reported that vegetables irrigated with contaminated water sources may be unsafe for human consumption [26, 50]. Some leafy vegetables grow quite well in the presence of sewage water [9]. The excessive accumulation of heavy metals in farmlands may not only result in environmental contamination, but also adversely affect the safety of farm produce including vegetables. Heavy metals uptake in vegetables is mainly through the roots and foliage of which root uptake from the soil is the dominant pathway [7].

Artisanal mining in Nigeria which dates back to several decades and have continued till date due to limited government investment in the sector and weak regulatory laws. Heavy metals contamination arising from mining is a major environmental concern on a global scale,

Corresponding author: Orish Ebere Orisakwe, Department of Experimental Pharmacology \& Toxicology, Faculty of Pharmacy, University of Port-Harcourt, Rivers State, Nigeria, e-mail: orishebere@gmail.com 
particularly in developing countries [61, 64]. Population close to the mine areas, especially children are all at risk of heavy metal exposure [38, 58]. Plateau state located in North Central Nigeria is the food basket of Nigeria but is also known for its age-long, uncontrolled artisanal mining with attendant public health consequences which is largely undocumented and unquantified. The contamination of farm produce and vegetables grown in the vicinity of Dilimi River, Bukuru and Barkin Ladi areas, Plateau State North Central Nigeria may be of public health concern due to artisanal mining sites.

Heavy metals such as $\mathrm{Pb}$ and $\mathrm{Cd}$ are known to be toxic even at low concentrations, while essential metals like $\mathrm{Fe}, \mathrm{Cu}, \mathrm{Zn}$ and $\mathrm{Co}$ become toxic as a result of increased consumption above the tolerable limit. Information about heavy metal concentration in food crops and their dietary intake which is main route of exposure is very important for assessing their health risk to human health [65]. Also soil to plant transfer is a major path of human exposure to metal contamination. Therefore it is important to monitor their concentrations in vegetables.

The study sought to assess some heavy metals uptake other than lead in vegetables and the potential health risks associated with human consumption of these vegetables from artisanal mining sites in Dilimi, Bukuru and Barkin Ladi villages in Jos North central, Plateau State, Nigeria.

\section{MATERIAL AND METHOD}

From January to December 2015 a total of 114 vegetable samples, 25 soil samples (50 $\mathrm{mm}$ depth), 9 irrigation water and sediments samples were collected from Dilimi, Bukuru and Barkin Ladi villages in Jos North central Nigeria. The sample locations were chosen from large vegetable farms within few kilometers to the urban centers that use the nearby Dilimi River for irrigation. Seven different kinds of leafy, root and legume vegetables were collected during the harvest period. They include Onions, Tomatoes, Cabbage, lettuce, Spinach, carrot, Green beans, Pepper, Beans and Irish potatoes. The following species of vegetable samples were used in this study, tomatoes Lycoperisicon esculentum, pepper: Capsicum anпuиm, Onion-Allium cepa, spinach, Spinacia oleracea, Carrot, Daurus carota, Cabbage, Brassica deracea, lettuce, Lactuca sati and Cucumber, Cucumis sativus. The soil and sediment samples were packed in polyethylene bags and brought from the sampling sites to the laboratory.

\section{Sample area}

The Jos Plateau lies in the middle belt of Nigeria. It is approximately $104 \mathrm{~km}$ from Nigeria, North to South, and $80 \mathrm{~km}$ from east to West covering an area of $8,600 \mathrm{~km}^{2}$. The Jos Plateau has steep escarpment edges with a descent of about $600 \mathrm{~m}$ to the surrounding plains. The Southern part of Jos Plateau is in the Benue Lowlands extending towards the River Benue flood plain. Jos Plateau is situated between latitudes $10^{\circ} 11^{\prime} \mathrm{N}$ and $8^{\circ} 55^{\prime} \mathrm{N}$ and longitude $8^{\circ} 21^{\prime} \mathrm{E}$ and $9^{\circ} 30^{\prime} \mathrm{E}$ (Figure 1). The study area (Bukuru-Jos) lies between latitudes $8^{\circ} 50^{\prime} \mathrm{N}$ and $9^{\circ} 00^{\prime} \mathrm{N}$ and longitude $9^{\circ} 45^{\prime} \mathrm{E}$ and $9^{\circ} 50^{\prime} \mathrm{E}$. It is about $8 \mathrm{~km}$ from Jos town and has total land area of $22 \mathrm{~km}^{2}$. Jos plateau is known for mining from ancient times. It has an average elevation of about 1,150 meters above sea level and the highest peak some $20 \mathrm{~km}$ eastwards from Jos-shere hill, rising to 1777 meters above mean sea level (Morgan, 1979). Dilimi River is the main drainage system of Jos.

\section{Preparation of samples}

The edible parts of all the vegetable samples were washed with tap water and rinsed in deionized water to remove soil and dust particles. The edible parts of vegetable samples were air-dried followed by oven drying at $65^{\circ} \mathrm{C}$ for $48 \mathrm{~h}$ to get rid of the moisture contents. Samples were powdered by a clean electric grinder. The dried edible parts of all the vegetable samples were sieved $(0.15 \mathrm{~mm})$ and then stored at room temperature until chemical analysis. Soil (50 $\mathrm{mm}$ depth) and sediment samples were oven dried at $105^{\circ} \mathrm{C}$ for $24 \mathrm{~h}$, ground in porcelain mortar and sieved through a 100 mesh $(30 \mathrm{~mm})$, and each sample was properly stored at $4^{\circ} \mathrm{C}$ until analysis. Water samples and sediments were collected in triplicate from each river used for irrigation. Water samples were preserved in pre-rinsed plastic bottles with $10 \%$ solution of $\mathrm{HNO} 3$ and stored at $4^{\circ} \mathrm{C}$. The edible part of the vegetable samples were also collected in triplicates from each sampling site.

\section{Analysis of samples}

Heavy metals $(\mathrm{Cd}, \mathrm{Cr}, \mathrm{Cu}, \mathrm{Zn}, \mathrm{Se}$ and $\mathrm{Ni})$ were analyzed in dried vegetables, soil and sediment samples. One gram of each dried sample was digested with $\mathrm{HNO} 3$ and $\mathrm{HCLO} 4$ in a $5: 1$ ratio at $80^{\circ} \mathrm{C}$ until a transparent solution was obtained [44]. Digestion of water samples was carried out according to the procedure reported by US EPA [53]. Well digested solutions of water, soil, sediments and vegetables samples were poured through Whatman filter paper No. 42 and volume was made up to $25 \mathrm{ml}$ with de-ionized water. Concentration of heavy metals were determined by Flame Atomic Absorption Spectrometer (FAAS Model S4 71096). All the analysis were done in triplicates.

\section{Quality control}

The instrument was recalibrated after every ten runs. The analytical procedure was checked using spike recovery method (SRM). A known standard of the metals was introduced into already analyzed samples and re-analyzed. The results of the recovery studies for $\mathrm{Cd}, \mathrm{Se}, \mathrm{Cr}, \mathrm{Cu}, \mathrm{Ni}$ and $\mathrm{Zn}$ were more than 
$95 \%$. The relative standard deviation between replicate analyses was less than $4 \%$. The limit of detection (LOD) for $\mathrm{Cd}, \mathrm{Se}, \mathrm{Cr}, \mathrm{Cu}, \mathrm{Ni}$ and $\mathrm{Zn}$ was $0.005 \mathrm{ppm}$, with blank values reading as $0.00 \mathrm{ppm}$ for all the metals in deionized water with electrical conductivity value of less than $5 \mu \mathrm{S} / \mathrm{cm}$. The limits of quantification LOQ for $\mathrm{Cd}, \mathrm{Cr}$ and $\mathrm{Ni}$ was $0.04, \mathrm{Cu}$ and $\mathrm{Zn}$ was
$0.06 \mathrm{ppm}$. Two-way analysis of variance (ANOVA) and a Student's t-test were used to determine whether the concentrations of the metals varied significantly, with values less than $0.05(\mathrm{p}<0.05)$ considered to be significant. The statistical calculations were performed with Graph Pad Prism 5.0.

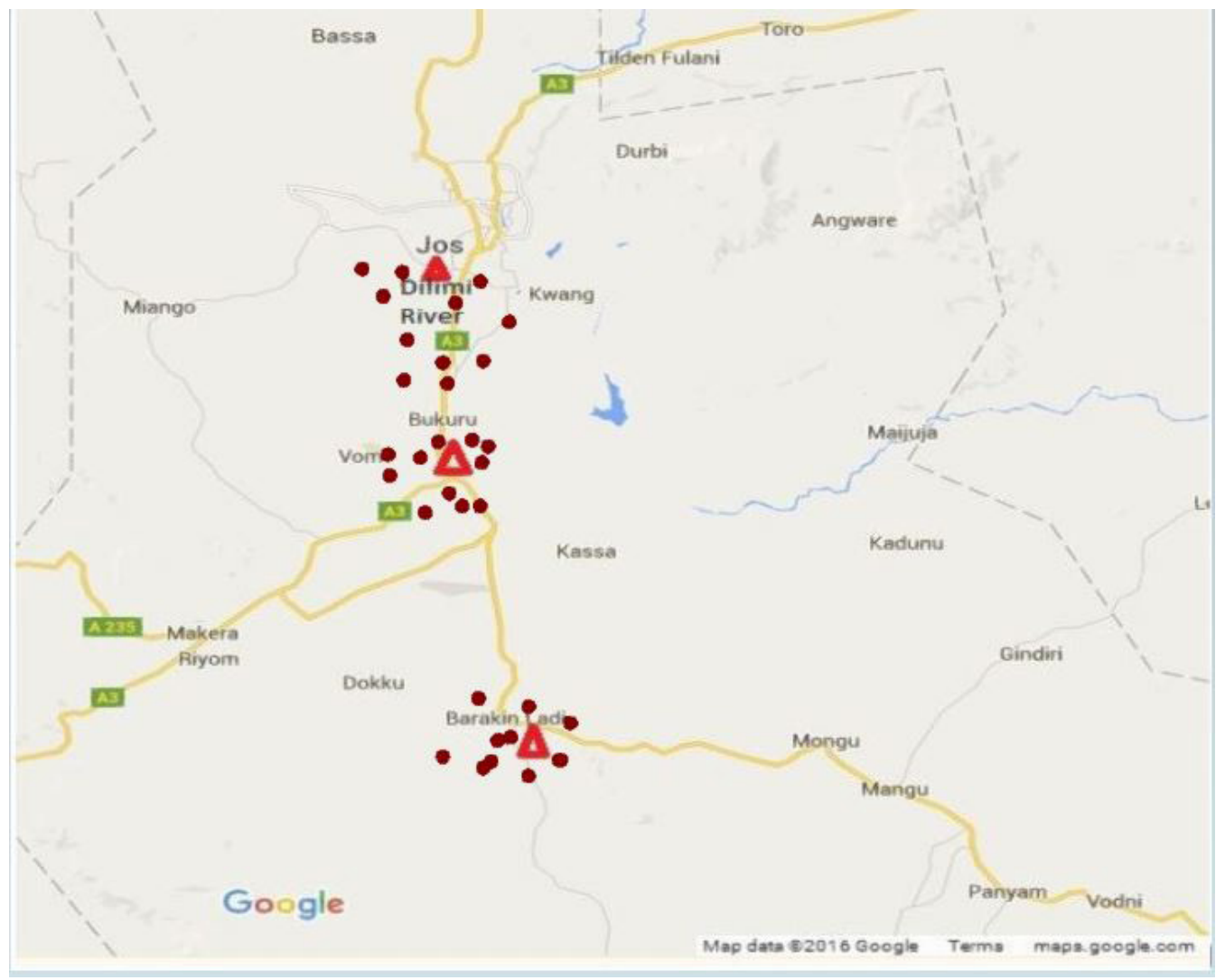

Figure 1. Location map of sampling sites in the study area.

\section{Health risk assessment calculation}

In order to evaluate the potential health risk of hazardous exposure to heavy metals via consumption of vegetables by the inhabitants of Dilimi, Bukuru and Barkin Ladi mining communities, the Estimated Daily Intake (EDI) and Target Hazard Quotient (THQ) were calculated. THQ is the ratio of the body intake dose of a pollutant to the reference dose that was first proposed by the United States Environmental Protection Agency (USEPA) for assessing the potential health risks of pollutant exposure to human health $[47,51]$. If THQ > 1 , there could be potential health risk associated with the pollutant. On the other hand, if THQ $<1$, then, there will be no obvious risk. Also to assess the overall potential for non-carcinogenic effects posed by more than one heavy metal, a Hazard Index (HI) approach was employed [55].

\section{Estimated Daily Intake (EDI)}

Daily intake of metals was calculated using the equation below;

$$
\mathrm{EDI}=\mathrm{C} \times \mathrm{IR} \times \mathrm{EF} \times \mathrm{ED} / \mathrm{BW} \times \mathrm{AT}
$$

Where:

$\mathrm{C}$ - is the mean concentration of a particular metal in a vegetable

IR - is a daily vegetable intake by the exposed population in Dilimi, Bukuru, Barkin Ladi. In the absence of food diaries and Total Diet Study data in Nigeria, we have employed 70 to $312 \mathrm{~g}$ per person per day intake rates of vegetables and fruits in Sub Saharan Africa [40],

EF - is the exposure frequency 350 days (US EPA 2011) [52],

ED - is the exposure duration of 53 years as the average life expectancy rate for a Nigerian adult according to world bank statistics [60],

$\mathrm{BW}$ - is the average weight of local residents $60 \mathrm{~kg}$ for adults and $25 \mathrm{~kg}$ for children aged $8-10$ years,

AT - is the average exposure time for non-carcinogens (exposure days within whole lifetime) 19345 days $=365 \times 53$, 
Target Hazard Quotient (THQ) was calculated using the following equation:

$$
\mathrm{THQ}=\mathrm{EDI} / \mathrm{RfD}
$$

Where:

EDI - is the estimated daily intake of heavy metals.

$\mathrm{RfD}$ - is the chronic oral reference dose for the heavy metals $\mathrm{Cd}, \mathrm{Cr}, \mathrm{Cu}, \mathrm{Ni}$, Se and $\mathrm{Zn}$ which are 0.001, 1.5, 0.04, 0.02, 0.005 and $0.3 \mathrm{mg} / \mathrm{kg} /$ day respectively $[54,59]$.

Hazard Index (HI) was calculated using the formula: $\mathrm{HI}=\Sigma \mathrm{THQ}$

Incremental Lifetime Cancer Risk (ILCR) is the lifetime probability of an individual developing any type of cancer due to carcinogenic daily exposure to a contaminant over a life time [28]. The ILCR is obtained using the Cancer Slope Factor (CSF) which evaluates the probability of an individual developing cancer from oral exposure to contaminant levels over a period of a lifetime as described by ATSDR [2] and it is contaminant specific [37]. $\mathrm{Cd}=6.10, \mathrm{Cr}=0.5$ (IRIS, 1991). Ingestion cancer slope factors are expressed in units of ( $\mathrm{mg} / \mathrm{kg} /$ day).

It was calculated using the equation below:

$$
\mathrm{R}=\mathrm{EDI} \times \mathrm{CSF}
$$

Where:

$\mathrm{R}$ - is the probability of excess lifetime cancer (or simply risk),

EDI - is the estimated daily intake of heavy metals.

CSF - is the carcinogenic slope factor,

\section{Bio-Concentration Factor (BCF) calculation}

Soil to plant bio-concentration factor was calculated as the ratio of metal concentration in plants to metal concentration in soils. The BCF was calculated by using the following equation as follows:

$$
\mathrm{BCF}=\mathrm{C}_{\text {vegetable }} \mathrm{C}_{\text {soil }}
$$

Where:

$\mathrm{C}_{\text {vegetable }}$ - is the total concentration of a particular heavy metal in the vegetable $\left(\mathrm{mg} \mathrm{kg}^{-1} \mathrm{dw}\right)$,

$\mathrm{C}_{\text {soil }}$ is the corresponding heavy metal concentration in the soil habitat of the vegetable $\left(\mathrm{mg} \mathrm{kg}^{-1}\right)$.

\section{RESULTS}

The concentration of heavy metals in the edible parts of the vegetable samples from Dilimi, Buruku and Barkin Ladi in Jos, North central Nigeria was in the order $\mathrm{Cd}<\mathrm{Se}<\mathrm{Cr}<\mathrm{Cu}<\mathrm{Ni}<\mathrm{Zn}$ (Table 1). Also the mean metal concentrations in Dilimi, Buruku and Barkin Ladi of Cd ranged between 0.004-0.199, $0.078-0.162$ and $0.037-0.155 \mathrm{mg} / \mathrm{kg}, \mathrm{Cr}$ varied within $0.424-2.08,0.82-2.06$ and $0.47-8.12 \mathrm{mg} / \mathrm{kg}, \mathrm{Cu}$ ranges from 1.1-15.12, 1.42-2.93 and 1.22-10.61, $\mathrm{Zn}$ ranged between 5.33-44.2, 5.1-11.33, 2.2-30.4 mg/kg, Se ranged between $0.0038-0.87,0.03-0.94$ and $0.003-$ $0.52 \mathrm{mg} / \mathrm{kg}$ and Ni ranges from 1.53-10.95, 3.43-3.8 and $2.87-8.68 \mathrm{mg} / \mathrm{kg}$ all showing large variations.

Table 1. Concentrations of heavy metals in vegetables from Dilimi, Bukuru and Barkin Ladi ( $\mathrm{mg} / \mathrm{kg}$ wet weight)

\begin{tabular}{lcccccc}
\hline Location site & Cadmium & Chromium & Copper & Zinc & Selenium & Nickel \\
\hline Dilimi & & & & & & \\
Onions & 0.0723 & 0.424 & 1.1 & 5.33 & 0.33 & 1.53 \\
Green beans & 0.0423 & 0.757 & 2.21 & 4.97 & 0.008 & 3.58 \\
Tomatoes & 0.094 & 0.66 & 1.97 & 7.9 & 0.4 & 4.38 \\
Cabbage & 0.199 & 1.12 & 3.72 & 6.96 & 0.79 & 4.85 \\
Lettuce & 0.094 & 2.08 & 15.12 & 44.2 & 0.87 & 10.95 \\
Spinach & 0.074 & 0.712 & 3.15 & 7.33 & 0.035 & 2.58 \\
Carrot & 0.08 & 1.29 & 2.4 & 11.2 & 0.5 & 4.62 \\
& & & & & & \\
Bukuru & & & & & & \\
Carrot & 0.137 & 2.06 & 2.93 & 11.33 & 0.42 & 3.8 \\
Cabbage & 0.078 & 0.82 & 2.04 & 5.1 & 0.94 & 3.43 \\
Tomatoes & 0.162 & 1.13 & 1.42 & 6.9 & 0.033 & 3.56 \\
& & & & & & \\
Barkin Ladi & & & & & & \\
Pepper & 0.119 & 0.86 & 1.79 & 5.44 & 0.124 & 3.13 \\
Beans & 0.0723 & 0.696 & 1.22 & 5.9 & 0.192 & 3.95 \\
Green beans & 0.155 & 1.562 & 1.31 & 5.5 & 0.11 & 4.85 \\
Lettuce & 0.069 & 1.12 & 10.61 & 30.4 & 0.52 & 8.68 \\
Irish potatoes & 0.037 & 8.12 & 2.38 & 2.5 & 0.0034 & 4.08 \\
Onions & 0.063 & 0.474 & 1.61 & 2.2 & 0.059 & 2.87 \\
Maximum Permissible Limit & $\mathbf{0 . 0 5}$ & $\mathbf{0 . 5}$ & $\mathbf{7 3 . 5}$ & $\mathbf{9 9 . 4}$ & & $\mathbf{0 . 6}$ \\
\hline
\end{tabular}


Table 2. Concentrations $(\mathrm{mg} / \mathrm{kg})$ of heavy metals in soil, water and sediments collected from Dilimi River, Bukuru and Barkin Ladi areas

\begin{tabular}{|l|c|c|c|c|c|c|}
\hline Location site & Cadmium & Chromium & Copper & Zinc & Selenium & Nickel \\
\hline \multicolumn{7}{|c|}{ Soil samples } \\
\hline Dilimi & 0.186 & 4.655 & 2.334 & 10.534 & 1.326 & 1.457 \\
\hline Bukuru & 0.972 & 28.812 & 15.093 & 35.694 & 2.743 & 10.324 \\
\hline Barkin Ladi & 0.762 & 13.488 & 11.832 & 35.139 & 3.136 & 7.032 \\
\hline European Union Standard & 3 & 150 & 140 & 300 & & 75 \\
\hline \multicolumn{7}{|c|}{ Water Samples } \\
\hline Dilimi & 0.0013 & $<0.001$ & 0.0019 & 0.0016 & $<0.001$ & 0.002 \\
\hline Bukuru & $<0.001$ & 0.0017 & 0.0253 & 0.0024 & 0.002 & $<0.001$ \\
\hline Barkin Ladi & $<0.001$ & 0.0013 & 0.0064 & $<0.001$ & $<0.001$ & 6.404 \\
\hline Austrian Standards & 10 & 100 & 200 & 2000 & & 200 \\
\hline \multicolumn{7}{|c|}{ Sediments } \\
\hline Dilimi & 0.894 & 6.634 & 4.978 & 6.328 & 1.409 & 9.149 \\
\hline Bukuru & 1.1376 & 11.061 & 7.438 & 14.416 & 3.706 & 16.104 \\
\hline Barkin Ladi & 2.3986 & 24.093 & 36.356 & 46.032 & 2.814 & 74.016 \\
\hline
\end{tabular}

Table 3. Estimated Daily Intake of heavy metals $\left(\mathrm{mg} / \mathrm{kg} \mathrm{day}^{-1} \mathrm{bw}^{-1}\right)$ from consumption of vegetables from Dilimi River, Bukuru and Barkin Ladi areas

\begin{tabular}{|c|c|c|c|c|c|c|c|}
\hline $\begin{array}{l}\text { Vegetables/ } \\
\text { Sample sites }\end{array}$ & & Cadmium & Chromium & Copper & Zinc & Selenium & Nickel \\
\hline \multicolumn{8}{|l|}{ Dilimi } \\
\hline \multirow[t]{2}{*}{ Onions } & adults & 3.6 E-04 & $1.2 \mathrm{E}-03$ & $5.5 \mathrm{E}-03$ & 2.6 E-02 & 1.6 E-03 & 7.6 E-03 \\
\hline & children & 2.0 E-04 & 1.5 E-03 & $3.1 \mathrm{E}-03$ & 1.5 E-02 & 9.2 E-04 & $4.3 \mathrm{E}-03$ \\
\hline \multirow[t]{2}{*}{ Green beans } & adults & $2.1 \mathrm{E}-04$ & 3.8 E-03 & $1.1 \mathrm{E}-02$ & 2.4 E-02 & 3.9 E-05 & $1.8 \mathrm{E}-02$ \\
\hline & children & $1.2 \mathrm{E}-04$ & 2.1 E-03 & $6.2 \mathrm{E}-03$ & 1.4 E-02 & $2.2 \mathrm{E}-05$ & $1.0 \mathrm{E}-02$ \\
\hline \multirow[t]{2}{*}{ Tomatoes } & adults & 4.7 E-04 & 3.3 E-03 & $9.8 \mathrm{E}-03$ & 3.9 E-02 & 1.9 E-03 & $2.2 \mathrm{E}-02$ \\
\hline & children & 2.6 E-04 & 1.8 E-03 & $5.5 \mathrm{E}-03$ & 2.2 E-02 & 1.1 E-03 & $1.2 \mathrm{E}-02$ \\
\hline \multirow[t]{2}{*}{ Cabbage } & adults & 9.9 E-04 & 5.6 E-03 & 1.9 E-02 & 3.4 E-02 & 3.9 E-03 & 2.4 E-02 \\
\hline & children & $5.6 \mathrm{E}-04$ & 3.1 E-03 & $1.4 \mathrm{E}-02$ & 1.9 E-02 & $2.2 \mathrm{E}-03$ & $1.4 \mathrm{E}-02$ \\
\hline \multirow[t]{2}{*}{ Lettuce } & adults & 4.7 E-04 & $1.02 \mathrm{E}-02$ & 7.5 E-02 & 2.2 E-01 & 4.3 E-03 & $5.5 \mathrm{E}-02$ \\
\hline & children & 2.6 E-04 & $5.8 \mathrm{E}-03$ & $4.2 \mathrm{E}-02$ & 1.2 E-01 & 2.4 E-03 & $3.1 \mathrm{E}-02$ \\
\hline \multirow[t]{2}{*}{ Spinach } & adults & 3.7 E-04 & 3.5 E-02 & $1.6 \mathrm{E}-02$ & 3.6 E-02 & 1.7 E-04 & $1.3 \mathrm{E}-02$ \\
\hline & children & $2.1 \mathrm{E}-04$ & $1.9 \mathrm{E}-03$ & 8.8 E-03 & $2.1 \mathrm{E}-02$ & 9.8 E-05 & 7.2 E-03 \\
\hline \multirow[t]{2}{*}{ Carrot } & adults & 4.0 E-04 & 6.4 E-03 & $1.2 \mathrm{E}-02$ & 5.5 E-02 & 2.5 E-03 & $2.3 \mathrm{E}-02$ \\
\hline & children & 2.2 E-04 & 3.6 E-03 & 6.7 E-03 & 3.1 E-02 & 1.4 E-03 & $1.3 \mathrm{E}-02$ \\
\hline \multicolumn{8}{|l|}{ Bukuru } \\
\hline \multirow[t]{2}{*}{ Carrot } & adults & 6.8 E-04 & 1.03 E-02 & 8.2 E-03 & 5.6 E-02 & 2.1 E-03 & 1.9 E-02 \\
\hline & children & 3.8 E-04 & 5.8 E-03 & $1.01 \mathrm{E}-02$ & 3.2 E-02 & 1.2 E-03 & $1.1 \mathrm{E}-02$ \\
\hline \multirow[t]{2}{*}{ Cabbage } & adults & 3.9 E-04 & 4.1 E-03 & $1.01 \mathrm{E}-02$ & $2.5 \mathrm{E}-02$ & $4.7 \mathrm{E}-03$ & 1.7 E-02 \\
\hline & children & $2.2 \mathrm{E}-04$ & $2.3 \mathrm{E} 03$ & 5.7 E-03 & 1.4 E-02 & 2.6 E-03 & $9.6 \mathrm{E}-03$ \\
\hline \multirow[t]{2}{*}{ Tomatoes } & adults & $5.6 \mathrm{E}-04$ & 5.6 E-03 & 7.2 E-03 & 3.4 E-02 & 1.6 E-04 & $1.8 \mathrm{E}-02$ \\
\hline & children & 4.5 E-04 & $3.2 \mathrm{E}-03$ & 3.9 E-03 & 1.9 E-02 & 9.2 E-05 & 9.9 E-03 \\
\hline \multicolumn{8}{|l|}{ Barkin Ladi } \\
\hline \multirow[t]{2}{*}{ Pepper } & adults & 5.9 E-04 & $4.3 \mathrm{E}-03$ & 8.9 E-03 & 2.7 E-02 & 6.2 E-04 & $1.6 \mathrm{E}-02$ \\
\hline & children & 3.3 E-04 & 2.4 E-03 & $5.01 \mathrm{E}-03$ & 1.5 E-02 & 3.5 E-04 & $8.8 \mathrm{E}-03$ \\
\hline \multirow[t]{2}{*}{ Beans } & adults & 3.6 E-04 & 3.5 E-03 & $6.1 \mathrm{E}-03$ & 2.9 E-02 & 9.6 E-04 & $1.9 \mathrm{E}-02$ \\
\hline & children & 2.0 E-04 & 1.9 E-03 & 3.4 E-03 & 1.7 E-02 & 5.4 E-04 & $1.1 \mathrm{E}-02$ \\
\hline \multirow[t]{2}{*}{ Green beans } & adults & 7.7 E-04 & 7.8 E-03 & $6.5 \mathrm{E}-03$ & 2.7 E-02 & 5.5 E-04 & $2.4 \mathrm{E}-02$ \\
\hline & children & 4.3 E-04 & 4.4 E-03 & 3.7 E-03 & 1.5 E-02 & 3.1 E-04 & 1.4 E-02 \\
\hline \multirow[t]{2}{*}{ Lettuce } & adults & 3.4 E-04 & $5.6 \mathrm{E}-03$ & $5.3 \mathrm{E}-02$ & 1.5 E-02 & 2.6 E-03 & $4.3 \mathrm{E}-02$ \\
\hline & children & 1.9 E-04 & 3.1 E-03 & 2.9 E-02 & 8.5 E-02 & 1.5 E-03 & 2.4 E-02 \\
\hline \multirow[t]{2}{*}{ Irish Potatoes } & adults & $1.8 \mathrm{E}-04$ & 4.0 E-02 & $1.2 \mathrm{E}-02$ & $1.2 \mathrm{E}-02$ & 1.7 E-05 & $2.0 \mathrm{E}-02$ \\
\hline & children & $1.0 \mathrm{E}-04$ & 2.3 E-02 & $6.6 \mathrm{E}-03$ & 7.0 E-03 & 9.5 E-05 & $1.1 \mathrm{E}-02$ \\
\hline \multirow[t]{2}{*}{ Onions } & adults & $3.1 \mathrm{E}-04$ & 2.4 E-03 & $8.01 \mathrm{E}-03$ & $1.1 \mathrm{E}-02$ & 2.9 E-04 & $1.4 \mathrm{E}-02$ \\
\hline & children & $1.8 \mathrm{E}-04$ & 1.3 E-03 & $4.5 \mathrm{E}-03$ & 6.2 E-03 & 1.7 E-04 & $8.0 \mathrm{E}-03$ \\
\hline
\end{tabular}


Table 2 is the concentrations of heavy metals in soil, sediments $(\mathrm{mg} / \mathrm{kg})$ and water from Dilimi River, Bukuru and Barkin Ladi mining areas. The mean concentrations of $\mathrm{Cd}, \mathrm{Cr}, \mathrm{Cu}, \mathrm{Zn}, \mathrm{Se}$ and $\mathrm{Ni}$ in farm lands from different villages varied significantly with values of $0.64,15.65,9.75,27.12,2.4,6.27 \mathrm{mg} / \mathrm{kg}$ respectively. The heavy metal levels in water and soil were below the maximum permissible levels set by European Union and Food and Agricultural Organization. Similarly the heavy metals concentrations in the water samples ranged from $<0.001-6.404(\mathrm{mg} / \mathrm{ml})$. The metal concentrations increased in the order $\mathrm{Ni}>\mathrm{Zn}>\mathrm{Cu}>\mathrm{Cr}>$ $\mathrm{Se}>\mathrm{Cd}$ and ranged from $0.89-74.02 \mathrm{mg} / \mathrm{kg}$.

The estimated daily intake EDI ( $\mathrm{mg} / \mathrm{day} / \mathrm{kg} /$ body weight) of heavy metals from consumption of studied vegetables in Dilimi, Bukuru and Barkin Ladi are presented in Table 3.

The estimated daily intake EDI decreased in the following order $\mathrm{Cd}<\mathrm{Se}<\mathrm{Cr}<\mathrm{Cu}<\mathrm{Ni}<\mathrm{Zn}$. Target hazard quotient (THQ) and Hazard index (HI) for adult and children exposed to farm produce and vegetables contaminated with heavy metals in Dilimi, Bukuru and Barkin Ladi mining areas are shown on Table 4. The THQ of nickel of green beans, tomatoes, cabbage, lettuce and carrot from Dilimi were greater than one. Similarly the THQ of nickel of beans, green beans, lettuce and Irish potatoes from Barkin Ladi were also greater than one. The THQ of nickel ranged from 0.382.73 and $0.21-1.53$ in adults and children respectively. A total of $62.5 \%$ of vegetable samples had THQ values $>$ 1 in Dilimi, Bukuru and Barkin Ladi (adults) while 13\% of vegetable samples had THQ values $>1$ in children.

The bio-concentration factor are presented in Figs $2-4$, with values ranging from $0.026-7.52,0.01-0.36$ and 0.0011-1.23 in Dilimi, Bukuru and Barkin Ladi respectively for all the studied heavy metals.

Table 4. THQ and HI for adults and children exposed to vegetables contaminated with heavy metals in Dilimi River, Bukuru and Barkin Ladi mining areas

\begin{tabular}{|c|c|c|c|c|c|c|c|c|}
\hline & & $\mathrm{Cd}$ & $\mathrm{Cr}$ & $\mathrm{Cu}$ & $\mathrm{Zn}$ & $\mathrm{Se}$ & $\mathrm{Ni}$ & $\begin{array}{r}\text { Hazard } \\
\text { Index }\end{array}$ \\
\hline \multicolumn{9}{|l|}{ Dilimi } \\
\hline \multirow[t]{2}{*}{ Onions } & adults & 0.36 & 0.07 & 0.14 & 0.09 & 0.33 & 0.38 & 1.37 \\
\hline & children & 0.20 & 0.04 & 0.08 & 0.05 & 0.18 & 0.21 & 0.76 \\
\hline \multirow[t]{2}{*}{ Green beans } & adults & 0.21 & 0.13 & 0.28 & 0.08 & 0.008 & 0.89 & 1.59 \\
\hline & children & 0.12 & 0.07 & 0.15 & 0.05 & 0.004 & 0.50 & 0.89 \\
\hline \multirow[t]{2}{*}{ Tomatoes } & adults & 0.47 & 0.11 & 0.25 & 0.13 & 0.39 & 1.09 & 2.44 \\
\hline & children & 0.26 & 0.06 & 0.14 & 0.07 & 0.22 & 0.61 & 1.36 \\
\hline \multirow[t]{2}{*}{ Cabbage } & adults & 0.99 & 0.19 & 0.46 & 0.11 & 0.79 & 1.21 & 3.75 \\
\hline & children & 0.56 & 0.10 & 0.26 & 0.06 & 0.44 & 0.68 & 2.1 \\
\hline \multirow[t]{2}{*}{ Lettuce } & adults & 0.47 & 0.35 & 1.88 & 0.72 & 0.86 & 2.73 & 7.01 \\
\hline & children & 0.26 & 0.19 & 1.06 & 0.41 & 0.49 & 1.53 & 3.94 \\
\hline \multirow[t]{2}{*}{ Spinach } & adults & 0.37 & 0.12 & 0.39 & 0.12 & 0.03 & 0.64 & 1.67 \\
\hline & children & 0.21 & 0.06 & 0.22 & 0.07 & 0.02 & 0.36 & 0.94 \\
\hline \multirow[t]{2}{*}{ Carrot } & adults & 0.39 & 0.21 & 0.29 & 0.18 & 0.49 & 1.15 & 2.71 \\
\hline & children & 0.22 & 0.12 & 0.17 & 0.10 & 0.28 & 0.65 & 1.54 \\
\hline \multicolumn{9}{|l|}{ Bukuru } \\
\hline \multirow[t]{2}{*}{ Carrot } & adults & 0.68 & 0.34 & 0.36 & 0.19 & 0.42 & 0.95 & 2.94 \\
\hline & children & 0.38 & 0.19 & 0.21 & 0.11 & 0.24 & 0.53 & 1.66 \\
\hline \multirow[t]{2}{*}{ Cabbage } & adults & 0.39 & 0.14 & 0.25 & 0.08 & 0.94 & 0.85 & 2.65 \\
\hline & children & 0.22 & 0.08 & 0.14 & 0.05 & 0.53 & 0.48 & 1.5 \\
\hline \multirow[t]{2}{*}{ Tomatoes } & adults & 0.81 & 0.19 & 0.18 & 0.11 & 0.03 & 0.89 & 2.21 \\
\hline & children & 0.45 & 0.11 & 0.09 & 0.06 & 0.02 & 0.49 & 1.22 \\
\hline \multicolumn{9}{|l|}{ Barkin Ladi } \\
\hline \multirow[t]{2}{*}{ Pepper } & adults & 0.59 & 0.14 & 0.22 & 0.08 & 0.12 & 0.78 & 1.93 \\
\hline & children & 0.33 & 0.08 & 0.13 & 0.05 & 0.07 & 0.44 & 1.1 \\
\hline \multirow[t]{2}{*}{ Beans } & adults & 0.36 & 0.12 & 0.15 & 0.09 & 0.19 & 0.98 & 1.89 \\
\hline & children & 0.20 & 0.06 & 0.08 & 0.06 & 0.11 & 0.55 & 1.06 \\
\hline \multirow[t]{2}{*}{ Green beans } & adults & 0.77 & 0.26 & 0.16 & 0.09 & 0.11 & 1.21 & 2.6 \\
\hline & children & 0.43 & 0.15 & 0.09 & 0.05 & 0.06 & 0.68 & 1.46 \\
\hline \multirow[t]{2}{*}{ Lettuce } & adults & 0.34 & 0.19 & 1.32 & 0.49 & 0.52 & 2.16 & 5.02 \\
\hline & children & 0.19 & 0.10 & 0.74 & 0.28 & 0.29 & 1.22 & 2.82 \\
\hline \multirow[t]{2}{*}{ Irish potatoes } & adults & 0.18 & 1.35 & 0.29 & 0.04 & 0.003 & 1.02 & 2.88 \\
\hline & children & 0.10 & 0.76 & 0.17 & 0.02 & 0.002 & 0.57 & 1.62 \\
\hline \multirow[t]{2}{*}{ Onions } & adults & 0.31 & 0.08 & 0.20 & 0.04 & 0.06 & 0.71 & 1.4 \\
\hline & children & 0.18 & 0.04 & 0.11 & 0.02 & 0.03 & 0.40 & 0.7 \\
\hline
\end{tabular}




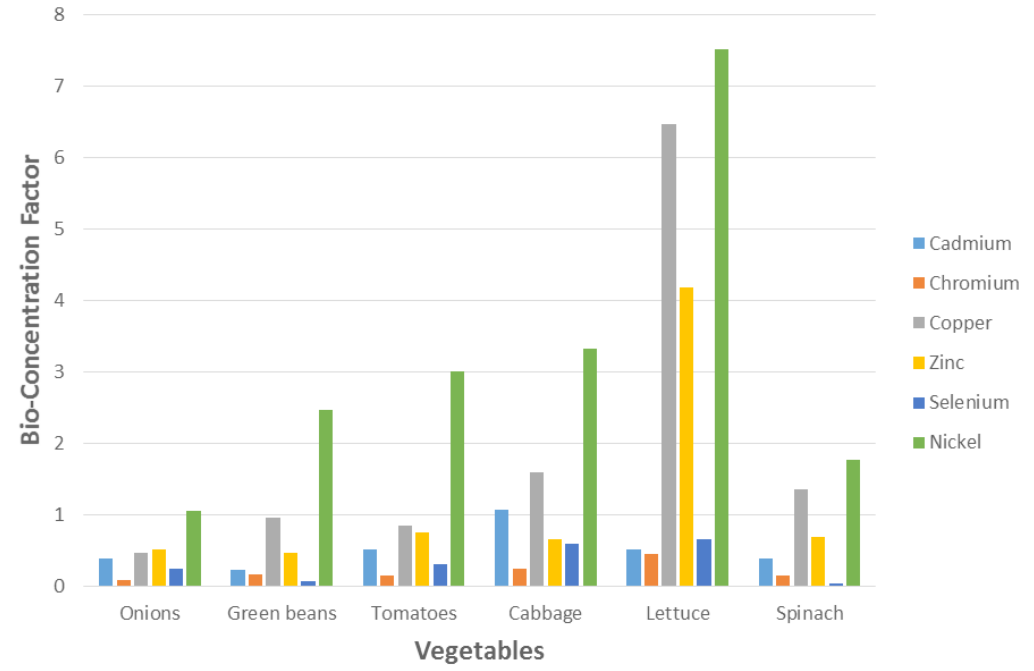

Figure 2. Bio-Concentration factor from soil to vegetables in Dilimi area.

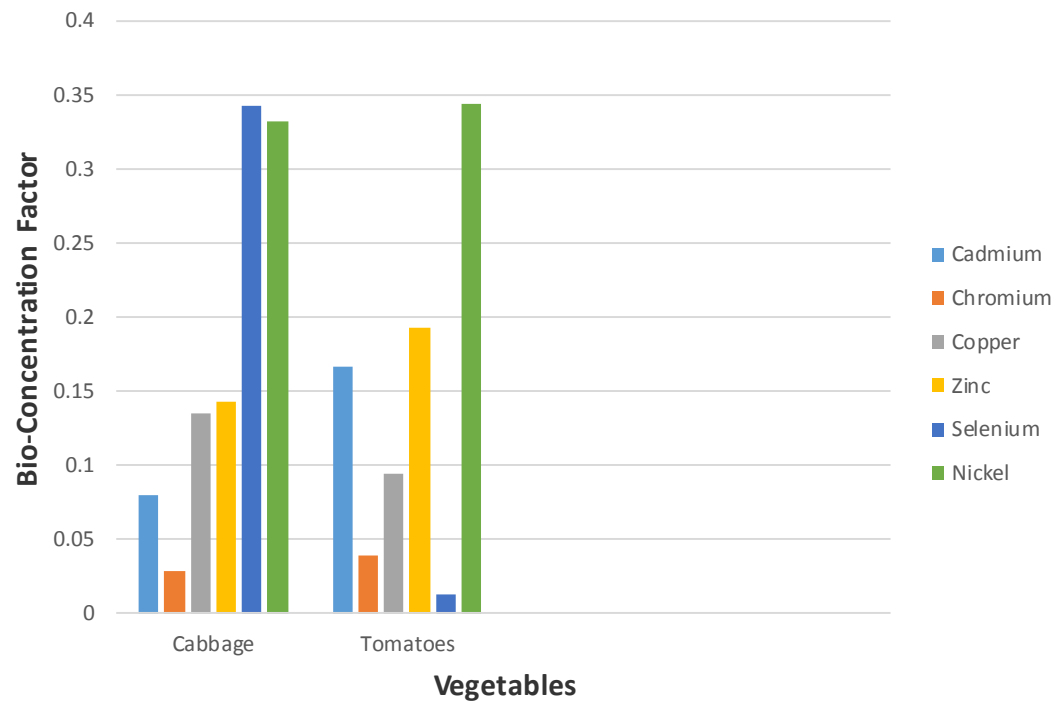

Figure 3. Bio-Concentration from soil to vegetables in Bukuru mining area.

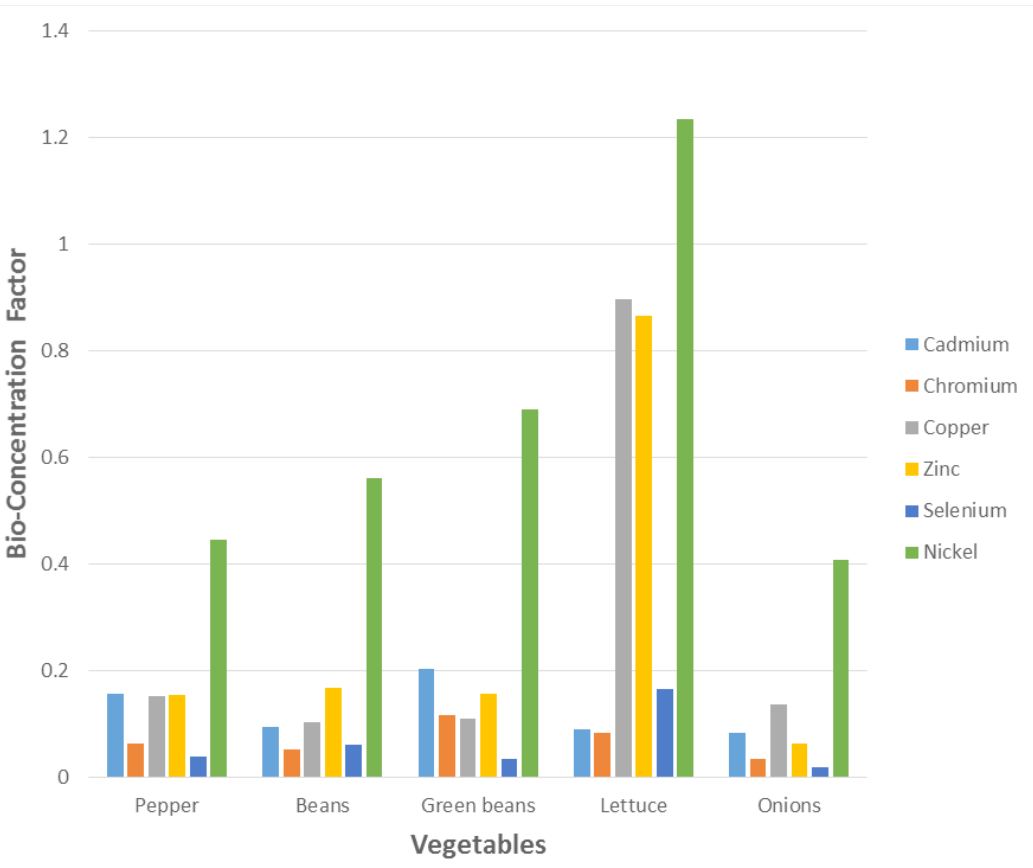

Figure 4. Bio-Concentration factor from soil to vegetables in Barkin Ladi mining area. 
Table 5 shows the cancer risk of $\mathrm{Cd}$ and $\mathrm{Cr}$ via oral consumption of vegetables. The cancer risk values ranged from $0.011-0.04$ and $0.00066-0.02$ across all the studied areas for adults and children respectively.

Table 5. Total Carcinogenic risks of cadmium and chromium for adults and children

\begin{tabular}{lcccc}
\hline Location & \multicolumn{2}{c}{ Adults } & \multicolumn{2}{c}{ Children } \\
\hline & $\mathrm{Cd}$ & $\mathrm{Cr}$ & $\mathrm{Cd}$ & $\mathrm{Cr}$ \\
Dilimi & 0.022 & 0.020 & 0.014 & 0.012 \\
Bukuru & 0.013 & 0.011 & 0.008 & 0.00066 \\
Barkin Ladi & 0.018 & 0.040 & 0.020 & 0.020 \\
\hline
\end{tabular}

\section{DISCUSSION}

Vegetables are important components of the human diet both in terms of consumed quantity and nutritional value $[39,46]$. Food safety is a major concern worldwide and this has accelerated research regarding the risk associated with food consumption contaminated by heavy metals $[3,32]$. Among farm produce, vegetables are the most susceptible to environmental pollution due to aerial burden and aerosol deposition [23].

The present study has investigated the health risk associated with the consumption of vegetables contaminated with heavy metals from Dilimi River, Bukuru and Barkin Ladi communities in North central Nigeria. There were variations in the heavy metal levels in the studied vegetables although the soil heavy metal concentrations were all within the maximum permissible limit of heavy metals in agricultural soil. The concentrations of metals from the different species of vegetables harvested form Dilimi, Bukuru and Barkin Ladi decreased in the order Lettuce $>$ Carrot $>$ Irish Potatoes $>$ cabbage $>$ Tomatoes $>$ Green beans $>$ Beans $>$ Onions. The ability of vegetables to sequester and accumulate heavy metals can be specie specific [43]. Lifetime exposure to low-dose carcinogenic metallic elements may be responsible for some types of cancer risks: a high risk of breast cancer has been linked to the consumption of $\mathrm{Cd}$ contaminated food [21]. Adequate public health policy for the protection of the local inhabitants, especially children, will include measures to remediate, reclaim and restore soils disrupted by persistent toxic metallic contaminants which bio-accumulate, bio-concentrate and bio-amplify up the food web $[17,30]$.

The variations in heavy metals concentration in analyzed vegetables could be due to variable uptake rate and accumulation of heavy metals in plants [36]. It is also known that the concentrations of these heavy metals in soil and their impact on ecosystems can be influenced by many factors, such as parent material, climate and anthropogenic activities [63].
The application of manures, fertilizers and pesticides may also account for the variations in the levels of contamination of heavy metals in soil [24]. The contamination of the agricultural soils with heavy metals were found in the order $\mathrm{Zn}>\mathrm{Cr}>\mathrm{Cu}>\mathrm{Ni}>\mathrm{Se}$ $>\mathrm{Cd}$ across the villages.

Although $\mathrm{Cd}$ concentration in soil was relatively lower than $\mathrm{Cr}$ and $\mathrm{Ni}$ concentrations in soil, the $\mathrm{Cd}$ concentrations in edible parts of vegetables were almost the same levels as the concentration detected in soil. The transfer factor of cadmium in vegetables is known to be quite high [23]. Cadmium is usually considered a highly mobile heavy metal as regards its uptake from soil to plants. It is easily absorbed by roots and transported to shoots $[10,22]$. In this study cadmium was detected in $100 \%$ of the analyzed samples though at concentrations below the maximum permissible limit $(0.2 \mathrm{mg} / \mathrm{kg})$, set by JECFA 2001 . Since most Nigerian cuisines are served with mixed vegetable, there may be additive cadmium toxicity that will exceed the maximum permissible limit 0.2 $\mathrm{mg} / \mathrm{kg}$. Vegetables may contribute to about $70 \%$ of Cd intake in man [57]. In recent years several studies from Romania [39], Pakistan [24], Iran [48] and China [47] have also reported vegetables and food crops cadmium levels higher than the Codex Alimentarius Commission (CAC) standard values (JECFA 2001). Soil and vegetables contaminated with $\mathrm{Cd}$ significantly contributed to decrease human life expectancy (9-10 years) in Copsa mica and Baia Mare, Romania, within the affected areas [27]. Cadmium has been listed as an endocrine-disrupting substance and exposure to this toxic metal through regular consumption of contaminated vegetables may lead to the development of prostate cancer and breast cancer [34]. Cadmium has deleterious health effect because it can be absorbed via alimentary tract; cross the placenta and elicit cell membrane and DNA damage.

The average concentration of $1.5 \mathrm{mg} \mathrm{Cr} / \mathrm{kg}$ in all vegetable samples in this study is 3 to 4 times higher than the level of $\mathrm{Cr}$ reported in vegetables from South China [7], Zhejiang China [35] and in plantain from Tarkwa area of Ghana [5]. Similarly the Cr level in the present study is higher than the $(0.168-1.926 \mathrm{mg} /$ $\mathrm{kg}$ ) reported in vegetables from Bangladesh [41], the levels of $\mathrm{Cr}$ ranged from $1.46-6.08 \mathrm{mg} / \mathrm{kg}$ in food crops irrigated with waste water in Pakistan [25]. At least $88 \%$ of the vegetable samples analyzed in the current study exceeded the maximum permissible limit for $\mathrm{Cr}$ in vegetables which is set at $0.5 \mathrm{mg} / \mathrm{kg}$ (JECFA 2001).

Among the vegetable samples collected from the three communities in the present study, all the sample exceeded the maximum permissible limit for nickel in vegetables. According to International Agency for Research on Cancer (IARC) evaluation, Ni compounds 
are carcinogenic to humans and are classified as Group 1 [20]. Nickel in the samples varied among the different communities with lettuce in Dilimi having the highest concentration of $10.95 \mathrm{mg} / \mathrm{kg}$, while the least concentration was observed in onions from Dilimi with a concentration of $1.53 \mathrm{mg} / \mathrm{kg}$. Ni ingestion can cause severe health problems, including fatal cardiac arrest, skin rashes, fatigue, headache, heart problems, dizziness and respiratory illness [33]. The levels of nickel in vegetables cultivated in Bangladesh [23], Libya [11] and China [22] are lower than the levels in our study.

Within the selected vegetable samples, metals like $\mathrm{Cu}$ and $\mathrm{Zn}$ had relatively higher concentrations when compared to $\mathrm{Se} . \mathrm{Cu}$ and $\mathrm{Zn}$ are essential metals for both plants and animals, but can also be toxic when they exceed physiological needs. The maximum levels of $\mathrm{Zn}$ in our study was detected in Lettuce $(44.2 \mathrm{mg} /$ $\mathrm{kg}$ ) collected from Dilimi. Also the highest level of $\mathrm{Cu}$ was in Lettuce $(15.12 \mathrm{mg} / \mathrm{kg})$, the levels were seen to be below the Maximum permissible limit for $\mathrm{Cu}$ in vegetables. There can also be health consequences arising from the deficiency of these essential metals which are key constituents of enzymes and proteins, as they play role in plant metabolism (Inmaculada 2005). Low Se in food is associated with cardiomyopathy and osteoarthropathy which have been observed in some parts of Russia and China $[1,49,56]$. Se was detected in all the vegetable samples at relatively low concentration ranging from $0.0034-0.94 \mathrm{mg} / \mathrm{kg}$ which is in agreement with the trend found in literature [19].

The bio-concentration factor (BCF) was calculated as the ratio of the metal concentration in the vegetables to the metal concentration in the soil. This is an index for evaluating the transfer potential of a metal from soil to plant [6]. Soil-to-plant transfer is one of the key components of human exposure to metals through the food chain [65]. $\mathrm{Cu}$ and $\mathrm{Zn}$ were the most abundant metal in vegetables in this study, as they are essential trace elements for plants. This can be seen in the high transfer factor for $\mathrm{Cu}$ and $\mathrm{Zn}$ in the vegetable samples across the three villages. The TF for nickel in Dilimi village were all greater 1 , this is an indication that the vegetables grown in this area could be contaminated via aerial or atmospheric deposition. Metals which have high transfer factor make their way to edible part of plant more easily than those with low transfer factor [31]. Although $\mathrm{Cr}$ concentration were high in agricultural soils, the levels were however lower in vegetable samples. This result is in agreement with the report of low mobility observed in $\mathrm{Cr}$ from soil to plants $[18,22]$.

Like in the work of Satpathy et al [ 42] the calculated EDI of heavy metals for adults were found to be higher than those of children due to more vegetable consumption by adults. The THQ values of heavy metals for adults from vegetable consumption was found to be in this decreasing order: $\mathrm{Ni}>\mathrm{Cu}>\mathrm{Zn}$ $>\mathrm{Cd}>\mathrm{Se}>\mathrm{Cr}$. The THQ values of heavy metals for children also showed similar trend as the adults. Ni has the highest THQ values ranging between $(0.4-3.06)$, followed by $\mathrm{Cu}$ and $\mathrm{Cd}$ with THQ values $>1$ in some vegetable samples, while others had THQ values $<1$. $\mathrm{Cd}$ and $\mathrm{Ni}$ in vegetables from our study is of public health concern. In children $\mathrm{Ni}$ and $\mathrm{Cu}$ ingestion has the maximum risk with THQ values $>1$ in few samples. The HI values for both adults and children were greater than 1 , respectively, indicating that both adults and children who consume locally grown vegetables in Dilimi, Bukuru and Barkin Ladi may be at high risk of heavy metals toxicity from exposure to combination of several toxic metals [29].

According to USEPA, ILCR less than 10-6 can be assumed as low risk region, 10-6 to 10-4 is moderate risk; and values above 10-4 are regarded as high risk region. The cancer risk for the exposed population in the study areas for adults \& children exceeded the acceptable cancer risk level of $1 \times 10-4$. Therefore the cancer risk level in these mining areas are unacceptable and is of public health concern to the local population that consume vegetables grown in Dilimi, Bukuru and Barkin Ladi.

\section{CONCLUSION}

The THQ values $>1$ in most of the vegetable samples and $\mathrm{HI}$ values $>1$ for adults in all the vegetable samples suggest human health risks in both adults and children from chronic consumption. This finding is of huge public health concern since Jos Plateau which is the main food basket of Nigeria.

\section{Conflict of interest}

The authors declare no conflict of interest.

\section{REFERENCES}

1. Abrahams P.W.: Soil, geography and human disease: a critical review of the importance of medical cartography. Progress in Physical Geography 2006;30(4):490-512.

2. ATSDR.Agency for toxic substance and disease registry, public health assessment and health consultation. CENEX supply and marketing, Incorporated, Quicy, Grant County, Washington. 2010

3. Avci H.: Heavy metals in vegetables irrigated with wastewaters in Gaziantep, Turkey: a review of causes and potential for human health risks. Fresenius Environ. Bull. 2013;22(1):146-151.

4. Balkhair K.S, Ashraf M.A.: Field accumulation risks of heavy metals in soil and vegetable crop irrigated with sewage water in western region of Saudi Arabia. Saudi J Biol Sci. 2016;23(1):S32-S44. 
5. Bortey-Sam N., Nakayama S.M., Akoto O., Ikenaka Y., Fobil J.N., Baidoo E., Mizukawa H. Ishizuka M.: Accumulation of heavy metals and metalloid in foodstuffs from agricultural soils around Tarkwa area in Ghana, and associated human health risks. Int. J. Environ. Research Public Health 2015;12(8):8811-8827.

6. Cao H., Chen J., Zhang J., Zhang H., Qiao L., Men Y.: Heavy metals in rice and garden vegetables and their potential health risks to inhabitants in the vicinity of an industrial zone in Jiangsu, China. J. Environ Sci. 2010;22(11):1792-1799.

7. Chang C.Y., Yu H.Y., Chen J.J., Li F.B., Zhang H.H., Liu C.P.: Accumulation of heavy metals in leaf vegetables from agricultural soils and associated potential health risks in the Pearl River Delta, South China. Environ Monitor Aassess. 2014;186(3):1547-1560.

8. Cheng $S$.: Heavy metal pollution in China: origin, pattern and control. Environ Sci Pollut Res. 2003;10(3):192-198.

9. Cobb G.P., Sands K., Waters M., Wixson B.G., Dorward King E.: Accumulation of heavy metals by vegetables grown in mine wastes. Environ Toxicol Chem. 2000;19(3):600-607.

10. Dong J., Mao W.H., Zhang G.P., Wu F.B. \& Cai $Y$. Root excretion and plant tolerance to cadmium toxicity-a review. Plant Soil Environ. 2007;53(5):193.

11. Elbagermi M.A., Edwards H.G.M., Alajtal A.I.: Monitoring of heavy metal content in fruits and vegetables collected from production and market sites in the Misurata area of Libya. ISRN Analytical Chemistry 2012.

12. European Union. Heavy Metals in Wastes, European Commission on Environment http://ec.europa.eu/ environment/waste/studies/pdf/heavy_metalsreport.pdf .2012 .

13. FAO/WHO. Proceedings of the 53rd Meeting of Joint FAO/WHO Expert Committee on Food Additives. Summary and Conclusions. Joint Expert Committee on Food Additives Rome, Italy. 1999.

14. FAO/WHO. Codex Alimentarius Commission. Food Additives and Contaminants. Joint FAO/WHO Food Standards programme, ALINORM 01/12A:1-289. 2001.

15. FAO. Water Quality for Agriculture. Paper No. 29 (Rev. 1) UNESCO, Publication, FAO, Rome. 1985

16. FAO/WHO. Joint FAO/WHO Food Standards Programme -Codex Alimentarius Commission. Report of the 33rd Session of the Codex Committee on Food Additives and Contaminants; FAO/WHO: Hague, the Netherlands 2001.

17. French C.J., Dickinson N.M., Putwain P.D,:. Woody biomass phytoremediation of contaminated brownfield land. Environ. Pollut. 2006;141,:387-395. http://dx.doi. org/10.1016/j.envpol.2005.08.065.

18. Huang M., Zhou S., Sun B., Zhao Q.: Heavy metals in wheat grain: assessment of potential health risk for inhabitants in Kunshan, China. Sci Total Environ. 2008;405(1): 54-61.

19. Hussein L., Bruggeman J.: Selenium analysis of selected Egyptian foods and estimated daily intakes among a population group. Food Chem. 1999;65(4):527-532.

20. IARC. A Review of Human Carcinogens: Metals, Arsenic, Fibres and Dusts, Vol. 100C, International
Agency for Research on Cancer: Monographs on the Evaluation of Carcinogenic Risks to Humans. 2012

21. Itoh H., Iwasaki M., Sawada N., Takachi R., Kasuga Y., Yokoyama S., Onuma H., Nishimura H., Kusama R., Yokoyama K., Tsugane S.: Dietary cadmium intake and breast cancer risk in Japanese women: a case-control study. Int. J. Hyg. Environ. Health, 2014; 217:70-77. http://dx.doi.org/10.1016/j.ijheh.2013.03.010

22. Jia L., Wang W., Li Y., \& Yang L.: Heavy metals in soil and crops of an intensively farmed area: a case study in Yucheng City, Shandong Province, China. Int. J. Environ. Research Public Health 2010;7(2):395-412.

23. Jolly Y.N., Islam A., Akbar S.: Transfer of metals from soil to vegetables and possible health risk assessment. Springer Plus, 2013; 2(1):1.

24. Khan K., Lu Y., Khan H., Ishtiaq M., Khan S., Waqas M., Wang T.: Heavy metals in agricultural soils and crops and their health risks in Swat District, northern Pakistan. Food Chem Toxicol. 2013;58:449-458.

25. Khan M.U., Malik R.N., Muhammad S.: Human health risk from heavy metal via food crops consumption with wastewater irrigation practices in Pakistan. Chemosphere, 2013;93(10):2230-2238.

26. Khan S., Cao Q., Zheng Y.M., Huang Y.Z., Zhu Y.G.: Health risks of heavy metals in contaminated soils and food crops irrigated with wastewater in Beijing, China. Environ. Pollut. 2008;152(3):686-692.

27. Lacatusu R., Rauta C., Carstea S., Ghelase I.: Soil plant relationships in heavy metal polluted areas in Romania. Appl. Geochem. 1996; 11:105-107

28. $\mathrm{Li}$ S., Zhang Q.: Risk assessment and seasonal variations of dissolved trace elements and heavy metals in the Upper Han River, China. J. Hazard. Mater. 2010;181(1):1051-1058.

29. Liu J., Zhang X.H., Tran H., Wang D.Q., Zhu Y.N... Heavy metal contamination and risk assessment in water, paddy soil, and rice around an electroplating plant. Environ. Sci. Pollut. Research, 2011;18(9):1623-1632.

30. Liu X., Song Q., Tang Y., Li W., Xu J., Wu J., Wang F., Brookes P.C.: Human health risk assessment of heavy metals in soil-vegetable system: a multi medium analysis. Sci. Total Environ. 2013;463-464, 530e540. http://dx.doi.org/ 10.1016/j.scitotenv.2013.06.064.

31. Luo C., Liu C., Wang Y., Liu X., Li F., Zhang G., Li X.: Heavy metal contamination in soils and vegetables near an e-waste processing site, south China. J. Hazard. Mater. 2011;186(1):481-490.

32. Mansour S.A., Belal M.H., Abou-Arab A.A., \& Gad $M . F .:$ Monitoring of pesticides and heavy metals in cucumber fruits produced from different farming systems. Chemosphere, 2009;75(5):601-609.

33. Muhammad S., Shah M.T., Khan S: Health risk assessment of heavy metals and their source apportionment in drinking water of Kohistan region, northern Pakistan. Microchem. J. 2011;98(2):334-343.

34. Pan J., Plant J.A., Voulvoulis N., Oates C.J., Ihlenfeld $C$ : Cadmium levels in Europe: implications for human health. Environ. Geochem. Health 2010;32(1):1-12.

35. Pan X.D., Wu P.G., Jiang X.G.: Levels and potential health risk of heavy metals in marketed vegetables in Zhejiang, China. Scientific reports, 6. 2016 
36. Pandey J., Pandey U.: Accumulation of heavy metals in dietary vegetables and cultivated soil horizon in organic farming system in relation to atmospheric deposition in a seasonally dry tropical region of India. Environ. Monitor. Assess. 2009;148(1-4):61-74.

37. Pepper I.L., Gerba C.P., Brusseau M.L.: Environmental and Pollution Science (Pollution Science Series), Academic Press, 2012; 212-232.

38. Plumlee G.S., Durant J.T., Morman S.A., Neri A., Wolf R.E., Dooyema C.A., Benzel W.M... Linking geological and health sciences to assess childhood lead poisoning from artisanal gold mining in Nigeria. Environ. Health Perspect. 2013;121(6):744.

39. Roba C., Roşu C., Piştea I., Ozunu A., Baciu C.: Heavy metal content in vegetables and fruits cultivated in Baia Mare mining area (Romania) and health risk assessment. Environ. Sci. Pollut. Research 2016;23(7):6062-6073.

40. Ruel M.T., Minot N. Smith L.: Patterns and determinants of fruit and vegetables in sub-saharan Africa: Multicountry comparison. A paper presented at Joint FAO/WHO Workshop on fruits and vegetables for health, 1-3 September, 2004, Kobe, Japan.

41. Saha N., Zaman M.R.: Evaluation of possible health risks of heavy metals by consumption of foodstuffs available in the central market of Rajshahi City, Bangladesh. Environ. Monitor. Assess. 2013;185(5):3867-3878.

42. Satpathy D., Reddy M.V., Dhal S.P: Risk Assessment of heavy metals contamination in paddy soil, plants, and grains (Oryza sativa L.) at the East Coast of India. BioMed Res. Int. 2014

43. Säumel I., Kotsyuk I., Hölscher M., Lenkereit C., Weber F., Kowarik I.: How healthy is urban horticulture in high traffic areas? Trace metal concentrations in vegetable crops from plantings within inner city neighborhoods in Berlin, Germany. Environ. Pollut. 2012;165:124-132.

44. Sharma R.K., Agrawal M., Marshall F.:. Heavy metal contamination of soil and vegetables in suburban areas of Varanasi, India. Ecotoxicol. Environ. Safety 2007;66(2):258-266.

45. Shi Y., Sullivan E.E., HolzbecherJ., ChattA.: Determination of selenium in Canadian food items by cyclic instrumental neutron activation analysis. Biol. Trace Elem. Res. 1999;71(1):377-386.

46. Siegel K.R., Ali M.K., Srinivasiah A., Nugent R.A., Narayan $K . V .:$ Do we produce enough fruits and vegetables to meet global health need?. PloS one, 2014;9(8):e104059.

47. Song D., Zhuang D., Jiang D., Fu J., Wang $Q$ :. Integrated health risk assessment of heavy metals in suxian county, south China. Int. J. Environ. Res. Publ. Health, 2015;12(7): 7100-7117.

48. Taghipour H., Mosaferi M: Heavy metals in the vegetables collected from production sites. Health Promot. Perspect. 2013;3(2):185.

49. Tan J.A., Zhu W. Wang W., Li R., Hou S., Wang D., Yang $L .:$ Selenium in soil and endemic diseases in China. Sci. Total Environ. 2002;284(1),:227-235.
50. Tom M., Fletcher T.D., McCarthy D.T.: Heavy metal contamination of vegetables irrigated by urban stormwater: a matter of time? PloS one, 2014;9(11):112441.

51. U.S. Environmental Protection Agency (USEPA). Region 9, preliminary remediation goals. http://www.epa.gov/ region09/waste/sfund/prg. Accessed 03 June 2016. 2002

52. US EPA. Exposure factors handbook 2011 edition (Final); 2011. http://cfpub.epa.gov/ncea/risk/recordisplay. cfm?deid $=236252$.

53. USEPA, 1990. Recommended protocols for measuring conventional water quality variables and metals in fresh water of the Puget Sound, 1200 6th Avenue Seattle, WA 98101. <http://www.psat.a.gov/Publications/protocols/ protocol_pdfs/accessed June 2016.

54. USEPA. Integrated Risk Information Syste Databas (IRIS) 2003. <http://www.epa.gov/IRIS> .

55. USEPA. Guidelines for the health risk assessment of chemicalmixtures [R]. Washington, DC:USEnvironmental Protection Agency; 1986 [EPA/630/R-98/002].

56. Ventura M.G., Stibilj V., Freitas M., Pacheco A.M.: Determination of ultratrace levels of selenium in fruit and vegetable samples grown and consumed in Portugal. Food Chem. 2009;115(1):200-206.

57. Wangner GJ.: Accumulation of cadmium in crop plants and its consequences to human health. Adv Agron 51:173-212. 1993

58. Wcisto E., Ioven D., Kucharski R., Szdzuj J: Human health risk assessment case study: an abandoned metal smelter site in Poland. Chemosphere, 2002;47(5):507-515.

59. WHO. Evaluation of certain food additives and contaminants (41st Report of the joint FAO/WHO expert committee on food additives), WHO Technical Report Series 837, World Health Organization, Geneva, Switzerland, 1993.

60. World Bank group, data.worldbank.org/indicators. [Accessed 5th June 2016]

61. Xu X., Zhao Y., Zhao X., Wang Y., Deng W.: Sources of heavy metal pollution in agricultural soils of a rapidly industrializing area in the Yangtze Delta of China. Ecotoxicol. Environ. Safety, 2014;108:161-167.

62. Yruela I.: Copper in plants. Brazilian J. Plant Physiol. 2005;17(1):145-156.

63. Zarcinas B.A., Ishak C.F., McLaughlin M.J., Cozens $G$ : Heavy metals in soils and crops in Southeast Asia. Environ. Geochem. Health 2004;26(4):343-357.

64. Zhuang P., Lu H., Li Z., Zou B., McBride M.B.: Multiple exposure and effects assessment of heavy metals in the population near mining area in South China. PloS one, 2014;9(4):94484.

65. Zhuang P., McBride M.B., Xia H., Li N., cLi Z.: Health risk from heavy metals via consumption of food crops in the vicinity of Dabaoshan mine, South China. Sci. Total Environ. 2009;407(5): 1551-1561.

Received: 31.10 .2017

Accepted: 10.08.2018

This article is available in Open Access model and licensed under a Creative Commons Attribution-Non Commercial 3.0.Poland License (CC-BY-NC) available at: http://creativecommons.org/licenses/by-nc/3.0/pl/deed.en 